\title{
針布線の錫鍍金と電解研磨(1)
}

（昭和24年 3 月 22 日受理）

$\begin{array}{llll}\text { 山 本 } & & \text { 光(2) } \\ \text { 今 } & \text { 西 } \text { 正 } \text { (3) }^{(3)}\end{array}$

緒

過去の廃集針布を絰計的倍えるとてれらは基 布中ヌはゼラチン糊の部分に於ける瞈針に依るも のである。ゼラチンの吸濕性に传るのか, 基布自 身の平衡水分飞依るのか，毛細窝密蝕て依つて錆 るのか，何机にしても疲学現象亡相俟つて脱針す るに至るすさ想像される。從て昔の「ピータ」 の如く錆に対して抵抗力の大なるものは壽命汃大 で有る事は考えられる。

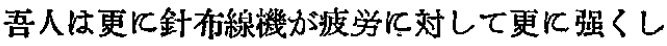
か子腐蝕に対する抵执力を大之するならば其の壽

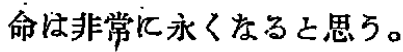

未來汇於て高電圧を利用して梳棉作朋を行つて んる時に於ては此の事を䠸えるのも無䭾ではなか らら。

\section{I 針布と疲勞現象}

針布は使用中は絕え方彈性的帘形を受けてている 斯る條件の下で称其の材料の强さは静的試驗に依 る破壤强度之は非常几異つてくる。即古材料汇荷 重を掛けたり取去つたりする之其の破壤强度より は藷しく低應力で壤れるすのである。今梳棉中 飞於りる針布の各々の針の最大應力を $\sigma$ max, 最 小應力を $\sigma \mathrm{min}$ とすると應力範围は

$$
\mathrm{S}=\sigma \mathrm{max}-\sigma \mathrm{min}
$$

其の平均應力は

$$
\sigma \mathrm{m}=\frac{1}{2}(\sigma \mathrm{m} \cdot \mathrm{ax}+\sigma \mathrm{min})
$$

したがつて一般に㚆化する亦ガのサイクルは

$$
\sigma \max =\sigma \mathrm{m}+-\frac{\mathrm{S}}{2} . \quad \sigma \mathrm{min}=\sigma_{1,1}-\frac{\mathrm{S}}{2}
$$

となる。作し使用妝態に於て針が何サイクルで变
化するか， $\sigma \max \sigma \min$ の價は其の時々の狀態化 依つて異なる篇一定の数字で表はす事は不可能で ある。

針て起る應力は一般て基布の柔軟度及び其の組 成，針の形狀（側磨の程度も非常飞大をくZ角部 分们於当丸み，牛径の大小依名應力集中程度 等も）飞より其の價が相当に㕠るものである。

基布の柔軟度を考虑せざる時は歪と應力の関係 は彈性力学的に求められるが; 基布の柔㜞及其の

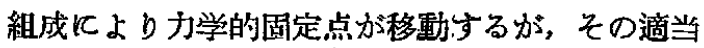
な計算方法が今考えられないから正確を式を求め る事は出來妨。

應力と撓の近似的算式としては東京工大の石川 章一氏壮

$$
\begin{gathered}
\delta / \mathrm{S}=\frac{3 \mathrm{EI}}{\mathrm{A}^{3} \mathrm{~F}}\left\{\delta_{3} \cos \left(\frac{2 x}{2}-x\right)\right. \\
+\mathrm{bccos} x-\mathrm{bc}(x+\mathrm{i}+\phi)\}
\end{gathered}
$$

と提唱されているがててれは長さAなる真直なる 片持梁としての撓みを求め，此れに $\delta / S$ となる 形狀率を使用して真の價に近づけようよされてい る。

針布の彈性即ち針頭に倚を受けた場合針顕の位 造が変化し其の变位が梳棉作用の最も大きい要溹 である以上，側暗の形狀も亦無視すべからざる大

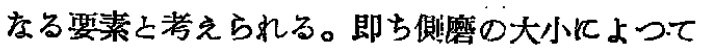
かなり撓み量が異なつたくるのである。（勿諭Z 角の所の丸味牛径にを影響するが）貞面な棒亡考 えるの之平等强さの棒之侾えるのとでは其の複み 量む蓄積し得る歪エネルギー量も相当異なる。何 れにせよ針の破壤は錆な々場合には疲学によ・b錆 た時には管蝕疲学に依り破壞するものであるから 吾人は疲労《対してより强く，しか子腐蝕に対し

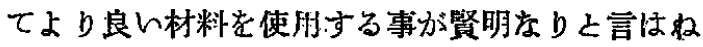

(1) Tingilding or electric grinding of card wire.

(2) H. YANAMOTO, 東亞針布株式会社工䭪長

(3) S. IMANISHI, 间研究課長 
ばならぬ。

而して疲学及腐蝕に詨しては非常に多くの荘素 に支配されて複䌖である。実驗に依れば鉄鍓材に

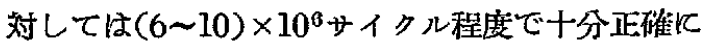
疲学限界が定められるのであるから針布を数ケ月 使用して基布の所から折れなければ実際的な使用 條件で注疲学に対して破壤しないと言える。從つ て我々か現在使用している線材之其の形狀に於て は疼学に依る破壤は起らない。（燒が硬過ざたり 亦は傷の䉆に應力集中をして壞れるのよは别に考 えられたり）即ち針布の脱針は腐蝕疲労で仿る， 此所に於て防銹と党命と少滵接なる意義を有する К至るのである。

其れでは不銹銅を使朋すればと思加るる゙加工。 の難易之其の市場飞於ける線材の生產性之経済的 事情に依り今よりはより良々針布線材に急沙行 する事は困難でする。勿論疲学限界の高く耐蝕性

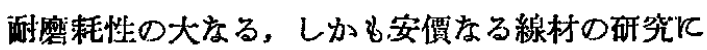
着手しているが急倿更する事は国難である。

從つて:各針狾会列: も今の線材にて其の加工処理 を变える事依つて亦は錫鍍金或は電解研感等の 表面処理に佉つて出來るだけ腐飿を少くし最後は 材質的变更に進まれるむのと思われるのである。

我々は針布製作後棝包して数年後の開罐に際し て錆て居らす，製作当時の如き美しき光沢を保持 せしめんよするには相包を利学的, 物琲的炕完全 なるものにすれば解決する或と思われる。

針が疲労に依つて破壞する時には基布の真中或

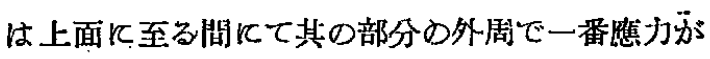
大之なるから破懐は此の部分加ら起る。先つ隹面 の点几亀裂を生じ其れが中心に向つて濑次進行す る。表面仕上狀態が惡くて孔溝等が有る場合には 隹力が集中する雼に龟裂は此の應力の最も高い所 に起る。此れを中心よして次第に㹡がつて破壞す

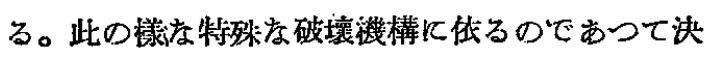
して結晶性に依るのではない。

疲労に估つて絬晶內に絊分の滑りを起す外には 全然变化しなん。

而して此妋に留蝕作用が件う事に依つて渚しく 促進されるのである。針有は使用中に於ては尖端 は絕えず穆こ作用するから鍗索いが一番應うの大

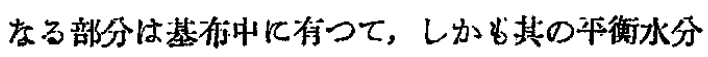

の侾在ゼラチン糊の吸濕性，時には毛細管糜蝕等 を惹起するから著しく惡條件中にある。

其れで現在針布線の防銹として考えらる鍍金法 と今一つ表面の分子を非常に小さくする高度の 研想とての両者に就て检討して見よう。針布線の 鍍金として考えられる事はクローム，カドミニー ム, 亞鉛, ニッケル, 牛田錫, 銅鍍金等であるが 其の內技術的，経済的に考察して探用されるもの はカドミ゙ューム，牛田，錫鍍金であらう。前記金 属は自己の薄膜により銓材の錆に対しては相当强 度化防ぐ事が出來るが，戏念乍ら技術的に完全な るものが岾來す線材の表面は「ザラ」付きが激 しくなり点ネとして密着せざる部分が出承て，此

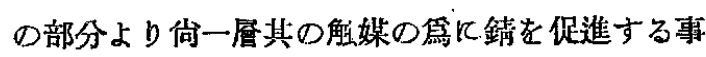
があり文膜厚くなる時は線材が非常に細をものな れば其の鍍金首の金属がカドミニーム錫等であれ ば其の脆さが大さく作肶て毞だしく折れ易くな 3o

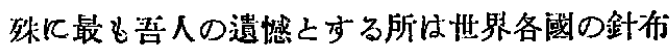

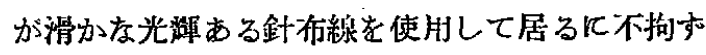
邦國製の針布のみが陳腐なる鍍金技衔に依らずば 防錆出來ざる樣では一步も二步も後退した事を游 外披露し技術の稚拙さを笑われるのではなかろ 亏か。

\section{II 使用中に於ける針布の針の 彈性と鍍金の關係}

使用中に於ては針は緮えす彈性的变形をうりる 其の歪化依つて表面住成する鍍金被膜を破 b局 部的に集中せる內力之電策化学的作用を゙て依つて 局部的腐蝕の素因を作り溝蝕を聕起する。而して てれイ依つて生成する凹所は更に內力が集中して 遂飞此の筒所より破壤して脫針するに至るのであ る。

此れを試驗する䉆に錫, 亞鉛, 錫, カドミウム 燐酸鉄被膜等の処置を施せる針布に一日数十回の 彈性的变形をさせ $3 \% \mathrm{Nacl}$ 溶液中にて腐蝕試驗 を行うと亞釭（ク口ム酸処理したもの）鉛, 錫, カドミウム燐酸鉄被膜の順であつた。

今針布線製造の見地より考えれば䉓篓鉏金は時。 䦐が非常に永くか」り結剧浸湞法に依るのが倩利 
であるが, 総て一䇰の厚され留着せしめる事は非 常に至嚾である。

\section{目電 解 䂰 磨}

鍍金が以上の理由を以て遠虑するよすれば今一 つは研朊である。我社は創業以來研磨に付ては非 常に苦心をしたのであるが，機械的研磨法として 一應は成功の域に達したが大なる設備と比較的コ ストが高く付く篇中止せり。元來針布線の如き細 々物は機械的研磨は非常に難かしんが最近電氣的

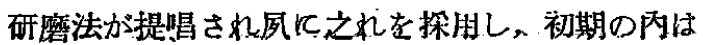

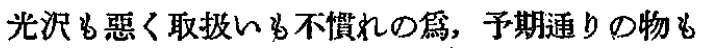
出柬ない䉆種々苦心の結果漸く針布線に適合せる 総ての條件も解決し笼に針布線に対する電解研磷 法完成せり。

膚の滑かさ青みがかつを蹬色，今迄の伸線に対す る附属雜工作の省略等其の利谷大なるものがあり

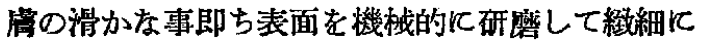
なしたるる同樣何其れ以上の好結果力゙得られる。

表面汃粗々亡腐蝕され易くなる事は不銹銓も研 㴪しなりれば銹性を示さない事からも明らかであ る。一般に粗なる面には水分は㠜縮し易く，した がつて平滑なる面に比して粗雜なる面には腐蝕吕 起り易ん。其の表面に傷とか小孔の存在する部分 には水分が永く保留し金属の研磨する事は腐蝕に 対して重慗な事である。而して伸線された輼では

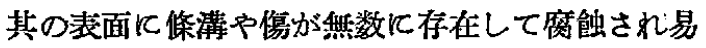
レ。したがつて電解研畗をなして鏡面光沪を呈せ

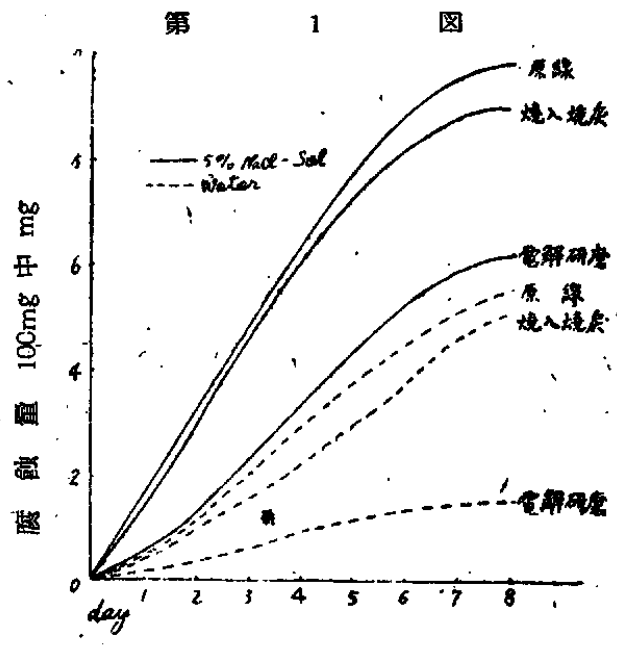

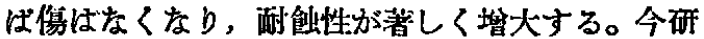
确したものんと，せなものの耐蝕性を比較すると 第 1 図の如し。

$\mathrm{C}=0.50 \%$ 鎦を電解研䐴したものとバフ仕上 したものとを测定液で電解液を形成せしめ其の起 電力を測定して見ると, 電位差は常に䉓解研礕し た面が大体 $0.1 \mathrm{~V}$ 前挠電池の陽極となつた。今雨 極面の電離溶区を電解の場合を $\mathbf{P}_{1}$ としバフの場 合を $\mathrm{P}_{2}$ とすると Nernst の式加ら $20^{\circ} \mathrm{C}$ に於 ては

$$
0 . \overline{1}=0.0582 / \log 10 \frac{P_{2}}{P_{1}} \quad P_{2} / P_{1} \fallingdotseq 2800
$$

となり酎銹性に対する目安となる。

田島氏は不銹錩に付んて電解面磨に於ては著し く酎銹性の增大する事を電氣化学䌖誌 14.41 (昭 21）に示されている。

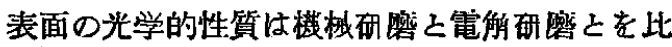
較して見ると，反射能は平厸約 $50 \%$ 高く且度射能 は機栈的研脴されたものでは一定でなく大体15～ 50\%の大きな開きがあり，同一表面でも5 7\%の 差が有り電解确嘼面では $1 \%$ 內外である。文機械 研磨では時間が経過すると反射能は少なくなるが 電解研磨しをむのば減少しなん。

即商品的價值に於ては著しく鍍金に優つている 亦研磨火依つて得られるるうつの利点は前にも 少し述べねが表面の仕上程度が良くなるにつれて

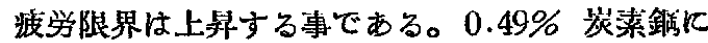

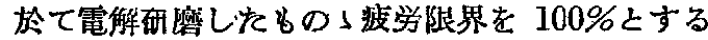
と仕上程度によつて即ち機树研㫘仕上 89 , 粗仕上 81となつた此の事実は針布の如く腐慨疲学に依つ て破壤する物には見のがす事の出來ない利点であ る。

以上に於て電解研碓と鉷金とに付いて洘察した が勿論窗蝕に対しては短時日をもつて絽論を下す 事は出来ないが，たら゙針布線《錫鍍金をする時に、 は表面の光沢及平滑さは電解研磨に劣る。此れは 亦植針時には線のもつれ之なり梳棉時には棉力:引 掛る亦鍍金は涂がれ易く側面柘磨，針孔等の存在

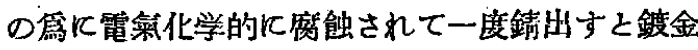
のしなんるの以上に早く銷るのではからうか。 
此の点に関してはクロム酸処理をせる亞鉛の方が

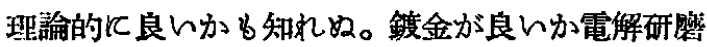
が良んかは数字的に表はせないが我々は電解研暨 の表面処理を探用すると共に更に根本的に腐蝕に 対して亦疲労に対して蚠い素材の使用を企図して

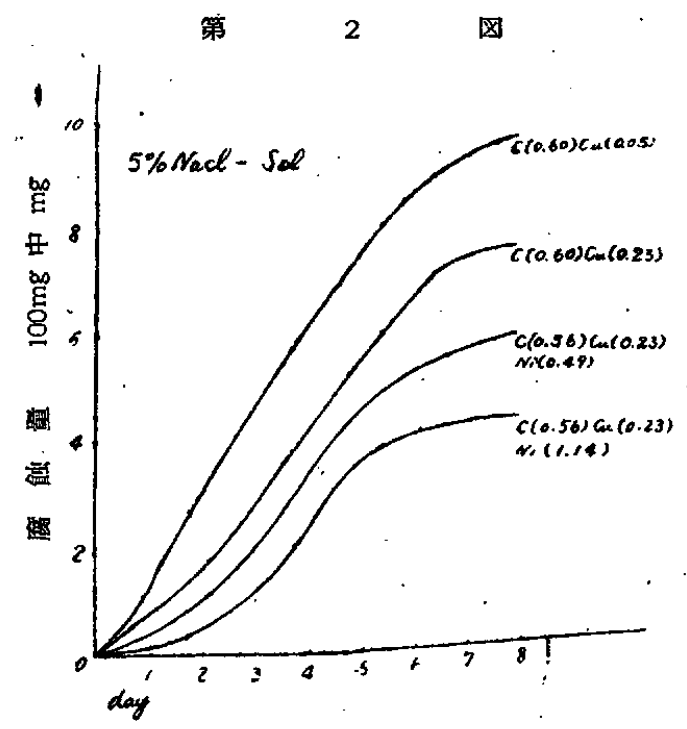

レる。此の素材の使用之電解窝磨に依つて更に針 布の套命は永くなるであらう。

\section{面含 銅 龬}

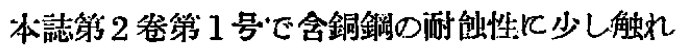
たが新し查針布線材に少し関係が有るから此所で もら少し精しく研究データを出したん。

鉄と銅の三合金に対しては Cornelius，Kup fer im Stahl (1940) 亦は Buch holy u. KO Sterstahl u. Eisen (1930), B $l 50$ S 867 等 くわしく書かれているのでする市，從來世界各國 に於ては首鋼を主要原料とする塩基性平炬製鍓法
が旺盛を極めた結果屑銅中《亦切削屑中の銅が混 入し一度鋼中に之が入ると取去る事は不可能で有 る。

之等を繰返し使用すると益々鋼材中に濃縮され る事は㫘れなん。

Houdremont-Sonderstahlkunde S 477 K低る とドイッに於ては近來凡ての鍓材は $0.2 \%$ 內外の 銅を含むと言われる。（瑞典銅は爿だ少ん）我國 では大冶の銅材を使用したものは0.15〜0.30\%位 合み昔の㴖洲照和製鋼所あたりの物では $0.01 \%$ 位 で其の量が不是”である。

以前は銅は銓飞赤脆性を與える物しして恐れら れてんたが，現在は鐝銅合金は殆んど調べ盡され 恐れる必裂無きのみなず却つて酎刢性及機栈的 性質の改善を見るのである。

一般に製品に仕上る迄火は高溫归熱及加工を、繰

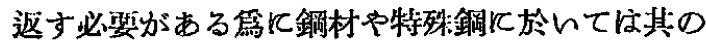
赤脆性の点から其の存在が楼度に婎はれたのであ るが， $0.8 \%$ 內外銅を含む鋼は其の $1 / 2$ 以上相当 するニツケルを㸝える赤脆性を抑制し強度酎創 性汃增加し又燒杘に依る折出硬化性を利用し得る 等の事寨より寧ろニツろル鋼中の=ツケルの一部 を銅に依つて置換せられるのでばなからうか。 佾鋼中の銅の一定含有量に対して一定量の满俺 亦はクローム等を州える之大氣及水の腐蝕に対す る抵抗力寉しく大となると共に優良な機械的性 質の物が得られる。即ち疲労亦は砶蝕疲労飞対し て非常に良栓兏線材が斯くの如をむの小中ら 得られるうである。

第 2 図はニッケル，銅の量のみを種々に変えた 場合の腐蝕試驗の一例である。 